\title{
Assessment of rectal Chlamydia trachomatis viable load in women by viability-PCR
}

Citation for published version (APA):

Janssen, K. J. H., Wolffs, P., Lucchesi, M., Dukers-Muijrers, N. H. T. M., \& Hoebe, C. J. P. A. (2020).

Assessment of rectal Chlamydia trachomatis viable load in women by viability-PCR. Sexually Transmitted Infections, 96(2), 85-88. https://doi.org/10.1136/sextrans-2019-054002

Document status and date:

Published: 01/03/2020

DOI:

10.1136/sextrans-2019-054002

Document Version:

Publisher's PDF, also known as Version of record

Document license:

Taverne

Please check the document version of this publication:

- A submitted manuscript is the version of the article upon submission and before peer-review. There can be important differences between the submitted version and the official published version of record.

People interested in the research are advised to contact the author for the final version of the publication, or visit the DOI to the publisher's website.

- The final author version and the galley proof are versions of the publication after peer review.

- The final published version features the final layout of the paper including the volume, issue and page numbers.

Link to publication

\footnotetext{
General rights rights.

- You may freely distribute the URL identifying the publication in the public portal. please follow below link for the End User Agreement:

www.umlib.nl/taverne-license

Take down policy

If you believe that this document breaches copyright please contact us at:

repository@maastrichtuniversity.nl

providing details and we will investigate your claim.
}

Copyright and moral rights for the publications made accessible in the public portal are retained by the authors and/or other copyright owners and it is a condition of accessing publications that users recognise and abide by the legal requirements associated with these

- Users may download and print one copy of any publication from the public portal for the purpose of private study or research.

- You may not further distribute the material or use it for any profit-making activity or commercial gain

If the publication is distributed under the terms of Article $25 \mathrm{fa}$ of the Dutch Copyright Act, indicated by the "Taverne" license above, 


\title{
Assessment of rectal Chlamydia trachomatis viable load in women by viability-PCR
}

\author{
Kevin J H Janssen (D) ,' Petra Wolffs, ${ }^{1}$ Mayk Lucchesi, ${ }^{1}$ Nicole H T M Dukers-Muijrers, ${ }^{1,2}$ \\ Christian J P A Hoebe ${ }^{1,2}$
}

'Department of Medical Microbiology, Care and Public Health Research Institute (CAPHRI), Maastricht University Medical Centre (MUMC+), Maastricht, The Netherlands ${ }^{2}$ Department of Sexual Health, Infectious Diseases and Environmental Health, South Limburg Public Health Service, Heerlen, The Netherlands

\section{Correspondence to} Dr Petra Wolffs, Department of Medical Microbiology, Care and Public Health Research Institute (CAPHRI), Maastricht University Medical Centre (MUMC+), Maastricht 6202 AZ, Netherlands; p.wolffs@mumc.nl

Received 6 February 2019 Revised 9 July 2019

Accepted 17 July 2019 Published Online First 5 August 2019

Check for updates

(C) Author(s) (or their employer(s)) 2020. No commercial re-use. See rights and permissions. Published by BMJ.

To cite: Janssen $\mathrm{KJH}$,

Wolffs P, Lucchesi M,

et al. Sex Transm Infect

2020;96:85-88

\begin{abstract}
Objectives In recent years, studies have demonstrated frequent rectal Chlamydia trachomatis (CT) detection in women, irrespective of reported anal sex or rectal symptoms. However, the clinical relevance and public health implication of rectal CT detection in women remain under debate. Therefore, evaluating $\mathrm{CT}$ viability may provide more insight into the relevance of standard routine nucleic acid amplification test (NAAT)-positive results.
\end{abstract}

Methods In this cross-sectional explorative study, a convenience sample of female patients at our STI clinic aged 18 years or older, diagnosed with vaginal and/ or rectal $\mathrm{CT}$, were invited to participate. On return for treatment, rectal CT-diagnosed women were instructed to self-collect rectal swab samples before being treated. Standard COBAS 4800 CT/NG routine NAAT testing was applied for CT diagnosis. Rectal viable CT load was evaluated by using viability-PCR (V-PCR).

Results 53 women with rectal CT were included in this study; $86.8 \%(46 / 53)$ had a quantifiable rectal total CT load. Of women with quantifiable samples, $52.2 \%$ (24/46) had viable CT detected from rectal swabs by $\mathrm{V}$-PCR, with a mean rectal viable CT load of $3.31 \log _{10}$ $\mathrm{CT} / \mathrm{mL}$ (range 1.16-6.22). No statistically significant difference $(p=0.73)$ was observed in the mean rectal viable CT load of women with an indication for rectal testing $(n=9)$ and without $(n=15), 3.20 \log _{10} \mathrm{CT} /$ $\mathrm{mL}$ (range 2.06-4.36) and $3.38 \log _{10} \mathrm{CT} / \mathrm{mL}$ (range 1.16-6.22), respectively. CT culture yielded positive test results from rectal swabs in $22.6 \%$ (12/53) of rectal CT NAAT-diagnosed women. Of women with viable rectal CT by V-PCR ( $n=24), 50 \%$ (12/24) were positive by CT culture.

Conclusions Overall, the detection of high rectal viable CT loads in this study indicates that rectal CT in some women might represent a currently ongoing infection rather than just the presence of remnant DNA from dead bacteria or only contamination from an active vaginal CT infection.

\section{INTRODUCTION}

Chlamydia trachomatis (CT) is the most commonly diagnosed bacterial STI worldwide. ${ }^{1}$ In women, vaginal CT infections may lead to serious complications such as pelvic inflammatory disease, ectopic pregnancy and infertility. ${ }^{2}$ Current testing guidelines regarding CT in women mainly focus on genital infections and recommend rectal testing only in case of self-reported anal sex or rectal symptoms (ie, selective testing on indication). ${ }^{3-5}$ However, it has become evident that the majority of women diagnosed with vaginal CT have a concurrent rectal CT infection, irrespective of reported anal sex or rectal symptoms. ${ }^{67}$ A part of the missed rectal CT infections might be coincidentally treated with azithromycin, due to the high concurrency of rectal CT in women diagnosed with a vaginal CT (summary estimate in STI-clinic women $68.1 \%$; $95 \%$ CI $56.6 \%$ to $79.6 \%) .{ }^{67}$ However, recent studies suggested that azithromycin may be less effective than doxycycline in clearing rectal CT infections $(82.9 \%$ (95\% CI $76.0 \%$ to $89.8 \%$ ) vs $99.6 \%$ (95\% CI $98.6 \%$ to $100 \%))^{8}$

In contrast to genital CT infections, the clinical relevance (ie, capacity to cause infection and morbidity) and public health implication (ie, transmission potential) associated with rectal CT infections in women are debated. ${ }^{9}{ }^{10}$ One of the key questions is whether rectal CT detection by nucleic acid amplification tests (NAATs) represents a true (ie, viable) rectal infection. Therefore, assessment of CT viability, an insight that has been lost with the expanded use of NAAT assays, may be vital to shed light on the current knowledge gaps regarding rectal CT in women. ${ }^{11}$

Recently, we validated the viability-PCR (V-PCR) method for the assessment of CT viability in clinical swab samples. ${ }^{12}$ This method combines the high sensitivity and specificity of PCR with the ability to distinguish between viable and dead bacteria based on membrane integrity. ${ }^{13-15}$ To our knowledge, this is the first study to assess the viable CT load in rectal swab samples from STI-clinic female patients. Thereby, results in this study may provide new insight into the clinical relevance of rectal CT detection in women.

\section{METHODS}

\section{Study population and procedures}

Study participants were recruited at our outpatient STI clinic of the South Limburg Public Health Service (GGD Zuid-Limburg) between November 2015 and April 2016. All women presenting to our STI clinic were tested for CT according to the current European STI testing guidelines (ie, rectal testing women only when reporting anal sex or rectal symptoms). ${ }^{4}$ Screening for CT in vaginal and rectal swab samples was performed by using the Cobas 4800 CT/NG NAAT assay (Roche Diagnostics, Basel, Switzerland). At the treatment visit, 
women aged 18 years or older, diagnosed with a symptomatic or asymptomatic vaginal or rectal CT infection, were asked to participate in this study (meaning a rectal swab at the treatment visit). Exclusion criteria were being pregnant, recent use of antibiotics ( $<1$ month) and having a concurrent infection with Neisseria gonorrhoeae.

At treatment visit, all consenting women were instructed by a study nurse to self-take two rectal swab samples (ie, insert the swab $2.5 \mathrm{~cm}$ into the anus, rotate it for 5 to $10 \mathrm{~s}$, and place the swab in a capped tube) before being treated with antibiotics (doxycycline). The first self-taken swab was placed in a capped tube containing CT transport buffer (2SP) and immediately stored at $4^{\circ} \mathrm{C}$. All samples for viability testing were transported within 24 hours to the Medical Microbiology Laboratory of the Maastricht University Medical Centre (MUMC+) by cooled transport. The second swab was used to confirm CT positivity at inclusion by using the routine diagnostic Cobas $4800 \mathrm{CT} / \mathrm{NG}$ NAAT assay (Roche Diagnostics).

\section{Viability testing by V-PCR}

Assessment of CT viability was achieved by using the V-PCR method as described previously with minor adaptions ${ }^{12}$ : in the current study, propidium monoazide (PMA) photoactivation was completed by using the PMA-Lite LED Photolysis Device (Biotium, Hayward, California, USA) with an exposure time of $10 \mathrm{~min}$. Furthermore, CT quantification was conducted in a total volume of $50 \mu \mathrm{L}$ to achieve a higher sensitivity.

Rectal swabs for viability testing were stored in $4 \mathrm{~mL} 2 \mathrm{SP}$ transport buffer. A total volume of $1 \mathrm{~mL} 2 \mathrm{SP}$ was used for V-PCR testing. The 2SP V-PCR sample was split into two aliquots of 500 $\mu \mathrm{L}$; one was used to evaluate the total CT load (untreated) and the other for viable CT load (PMA treated). The resulting cycle of quantification $(\mathrm{Cq})$ values were entered into a master calibration curve and log transformed to calculate the corresponding CT load $\left(\log _{10} \mathrm{CT} / \mathrm{mL}\right)$, as described previously. ${ }^{12}$ Samples without a qPCR signal within 42 PCR cycles were defined as unquantifiable $(13.2 \%(n=7)$ of rectal samples).

\section{Viability testing by culture}

All rectal CT NAAT-positive samples were subjected to CT culture, as previously described. ${ }^{16}$ In short, $500 \mu \mathrm{L}$ 2SP sample was inoculated on monolayers of cycloheximide-treated HeLa cells (ACC 57; DSMZ, Braunschweig, Germany) in four-well Nunc Cell Culture-treated plates (Thermo Fisher Scientific, cat. no. 176740) and centrifuged at $900 \mathrm{~g}$ for 1 hour at $37^{\circ} \mathrm{C}$. Cultures were stained with the primary mouse anti-CT major outer membrane protein monoclonal antibody (Virostat, Portland, Maine, USA) and the secondary fluorescein isothiocyanate conjugated rabbit-anti-mouse antibody (DakoCytomation, Glostrup, Denmark) 72 hours post-infection.

\section{Statistical analysis}

Load values acquired by qPCR were log transformed for analyses. Total and viable rectal CT load values were compared between women with and without indication for rectal testing by using a Mann-Whitney U test. Distribution of CT culture-positive results were compared between women with and without indication for rectal testing by $\chi^{2}$ analyses. In this study, women were categorised based on indication for rectal CT screening at the initial STI clinic visit: (1) indication for rectal testingreporting anal sex (previous 6 months) or rectal symptoms, and (2) no indication for rectal testing-reporting no anal sex or no rectal symptoms. ${ }^{4}$ All statistical analyses were performed using

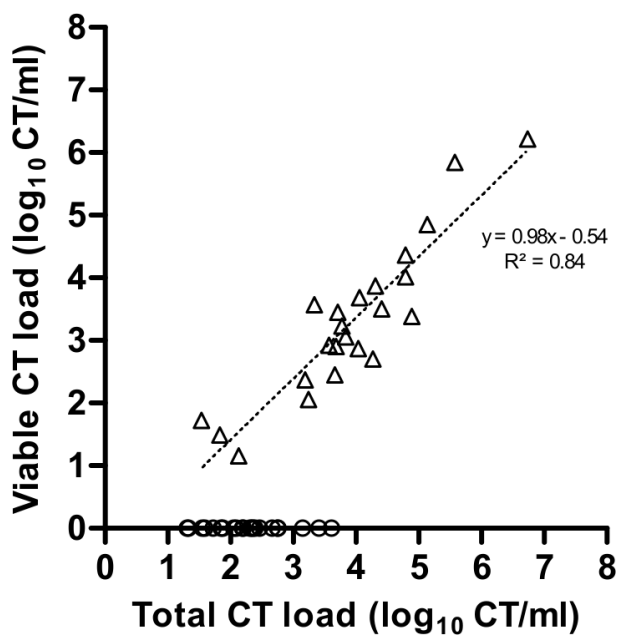

Figure 1 Total and viable rectal Chlamydia trachomatis (CT) load in women. Total and viable $\mathrm{CT}$ load $\left(\log _{10} \mathrm{CT} / \mathrm{mL}\right)$ in rectal swabs from women with quantifiable samples $(n=46)$. Triangles indicate samples with a viable CT load (24/46) and circles indicate samples without any evidence of viable CT (22/46).

GraphPad Prism V.5.03 for Windows (GraphPad Software, San Diego, California, USA), and a p value of $<0.05$ was considered statistically significant.

\section{RESULTS}

\section{Study population}

In total, 54 rectal CT NAAT-positive women were included in this study. The median age of women was 22 years (IQR, 20-24 years). Of these women, $94.4 \%(n=51)$ were diagnosed with a concurrent vaginal CT infection and 5.6\% $(n=3)$ had a rectalonly infection, according to routine systematic NAAT testing of both anatomical sites. Of all rectal CT-diagnosed women $(\mathrm{n}=54), 37.0 \%(\mathrm{n}=20)$ reported anal sex or rectal symptoms (ie, women having an indication for rectal testing according to current testing guidelines).

\section{Total and viable load of rectal CT in women}

In total, 53 2SP samples from CT NAAT-positive women were evaluated by V-PCR. One sample was not tested due to missing 2SP sample material. Quantification of total CT was achieved in $46(86.8 \%)$ 2SP samples. The remaining NAAT-positive samples $(\mathrm{n}=7 ; 13.2 \%)$ did not yield any quantification results, most likely due to a lower sensitivity of our in-house V-PCR (singletarget) compared with the commercial NAAT (multi-target) for the detection of CT.

The total and viable rectal CT load of quantifiable samples $(n=46)$ are plotted in figure 1 . V-PCR showed that viable CT were detected in 24/46 (52.2\%) 2SP samples (indicated by triangles), while for the remaining samples $(22 / 46 ; 47.8 \%)$, no evidence of viable CT was detected after PMA treatment (indicated by circles). Overall, quantification of total CT in rectal samples from women yielded a mean total CT load of $3.15 \log _{10}$ $\mathrm{CT} / \mathrm{mL}$ (range 1.31-6.74) and for viable CT this was $3.31 \log _{10}$ $\mathrm{CT} / \mathrm{mL}$ (range 1.16-6.22).

\section{Total and viable CT load in women by indication for rectal testing}

The rectal mean total and viable CT load from NAAT-positive women stratified by having an indication for rectal testing are shown in figure 2. In women with quantifiable samples (46/53), 


\section{A}

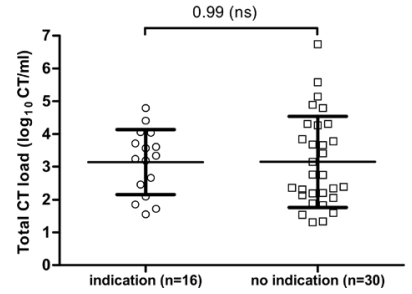

B

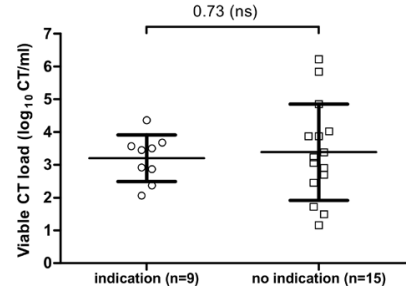

Figure 2 Total and viable rectal Chlamydia trachomatis (CT) load in women by indication for rectal testing. The mean total $(A)$ and viable (B) CT load $\left(\log _{10} \mathrm{CT} / \mathrm{mL}\right.$ ) in rectal swabs from women with (circles) and without (squares) an indication for rectal testing. Bars indicate the mean CT load value and whiskers represent the SD.

the rectal mean total CT load in women with indication for rectal testing (16/46) was $3.14 \log _{10} \mathrm{CT} / \mathrm{mL}$ (range 1.55-4.79) and in women without indication (30/46) this was $3.15 \log _{10}$ $\mathrm{CT} / \mathrm{mL}$ (range 1.31-6.74). In women with viable CT detected by V-PCR (24/46), the mean viable CT load in women with indication (9/24) was $3.20 \log _{10} \mathrm{CT} / \mathrm{mL}$ (range 2.06-4.36) and in women without indication $(15 / 24)$ this was $3.38 \log _{10} \mathrm{CT} / \mathrm{mL}$ $(n=15$; range $1.16-6.22)$. No statistically significant difference was observed in both the mean rectal total $(p=0.99)$ and viable $(\mathrm{p}=0.73)$ CT load between women with and without an indication for rectal testing (figure $2 \mathrm{~A}, \mathrm{~B}$ ).

Furthermore, no statistically significant difference $(p=0.69)$ was found in the proportion of samples with no evidence of viable CT (an absent $\mathrm{QPCR}$ signal after PMA treatment) and samples containing viable CT (detectable CT load after PMA treatment) between women with and without an indication for rectal testing.

\section{CT culture}

Assessment of CT viability by traditional culture showed a positive culture result in $22.6 \%(12 / 53)$ of rectal CT NAATdiagnosed women. Of women with viable rectal CT by V-PCR $(n=24), 50 \%(12 / 24)$ also tested positive in CT culture, while all women without any evidence for viable rectal CT $(n=22)$ or with unquantifiable rectal samples $(n=7)$ were negative by CT culture. Furthermore, culture-positive rates were similar $(p=0.84)$ for rectal swab samples from women with indication for rectal CT testing $(21.1 \% ; 4 / 19)$ and without $(23.5 \% ; 8 / 34)$.

\section{DISCUSSION}

This is the first study to report the viable CT load in rectal samples from female patients at an STI clinic. We detected viable CT in rectal samples from CT NAAT-positive women visiting our STI clinic. Furthermore, this study showed that comparable amounts of viable CT were detected in rectal samples from women reporting anal sex or rectal symptoms and without reporting such factors.

Based on previous studies assessing the prevalence of extragenital CT, it has become evident that rectal CT infections are common in women, and notably, the majority of these women did not report a plausible source of infection (eg, reporting anal sex). ${ }^{67}$ Yet, it is unclear whether rectal CT detection in women are true infections or not because routine diagnostic tests cannot distinguish between DNA from viable (able to be transmitted and cause complications) and non-viable (not transmissible) CT. The current study showed that in about half $(47.8 \%)$ of rectal CT-diagnosed women, no viable CT were detected by V-PCR, suggesting that there might be a possible overestimation of rectal
CT positivity in women by current routine diagnostic tests. Furthermore, V-PCR showed that relevant amounts of viable CT (mean viable CT load $3.31 \log _{10} \mathrm{CT} / \mathrm{mL}$, range 1.16-6.22) could be observed in half of the rectal CT-diagnosed women, suggesting that rectal CT detection in these women might represent true infection rather than just the presence of remnant DNA from dead CT or only contamination from an active vaginal infection. It has been previously hypothesised that rectal CT infection in women (besides unprotected anal intercourse with a CT-infected partner) might originate from autoinoculation via vaginal CT-infected secretions or colonisation of the gastrointestinal tract after oropharyngeal infection. ${ }^{9}{ }^{17}$ Although the source of rectal CT infection in women remains unclear, if left untreated, rectal CT infections may serve as a potential reservoir for ongoing infection.

Within the small study population $(n=53)$, no statistically significant difference $(p=0.73)$ was observed in the mean rectal viable CT load of women with and without an indication for rectal testing. This is consistent with previous studies reporting no association between rectal CT detection in women and reported history of anal sex or rectal symptoms. ${ }^{67}$ In the current study, only one-third of rectal CT diagnoses would have been treated adequately (ie, doxycycline treatment for rectal CT) based on current European guidelines. ${ }^{4}$ Furthermore, the majority of rectal CT diagnoses $(64 \% ; 34 / 53)$ would not have been tested for. Because all missed rectal CT diagnoses were observed in women with a concurrent vaginal CT, rectal CT would have been coincidentally treated with azithromycin. However, previous studies suggested that doxycycline may be more effective than azithromycin in treating rectal CT. Still, the complications (short and long term) and transmissibility associated with untreated or suboptimal treated rectal CT infections in women are still unclear and warrant future research.

The evaluation of CT viability in rectal samples by V-PCR is feasible and valid. Previously, we validated the V-PCR method in vaginal samples from women. ${ }^{12}$ In the current study, CT culture has been conducted as a validation approximation of CT viability for V-PCR and showed that samples with no evidence for viable CT or samples with an unquantifiable total load were also negative for CT culture.

Nevertheless, this study had several limitations. The study population was relatively small $(n=53)$. However, in a currently ongoing follow-up study (FemCure study), we are planning to assess CT viability in a larger cohort of $>500$ women. ${ }^{18}$ Furthermore, as self-report of anal sex (and rectal symptoms) may be subject to social desirability bias, we cannot rule out misclassification in some women (ie, women classified as no indication for rectal testing while having a history of anal sex). However, the questionnaire was anonymous and self-administered, thus the effect of reporting bias was likely to be limited. Moreover, the proportion of women reporting anal sex in the current study $(24 \% ; n=13 / 54)$ is comparable with the prevalence of anal sex in women found by previous studies (van Liere et al (19\%) and Benson et al (13\%)). ${ }^{619}$ Furthermore, questionnaires were taken at the time of initial screening, while the time interval between screening and return for treatment may have an effect on the (viable) CT load found at inclusion. The overall CT viability in this study may have been underestimated. Patients were instructed to insert the swab $2.5 \mathrm{~cm}$ into the anus, as recommended by our standard routine CT NAAT sampling procedures. Therefore, patient-collected rectal swabs in this study might contain mostly squamous epithelial cells, while columnar epithelial cells (located in the lower rectum) are suggested to be the preferred cells for CT infection and replication. Furthermore, the overall 
CT viability could have been underestimated due to bacterial cell death during transport, as discussed previously. ${ }^{12}$ As our outpatient clinic does not facilitate the direct evaluation of CT viability, samples were immediately stored in transport buffer at $4^{\circ} \mathrm{C}$ and transported to the central laboratory on dry ice $\left(-70^{\circ} \mathrm{C}\right)$ within the same day. Although sample storage and transport conditions were according to standard culture protocols, we cannot rule out CT viability loss. Therefore, CT viability could have been underestimated. A previous culture-based study showed that compared with direct inoculation, samples stored for 24 hours at $4^{\circ} \mathrm{C}$ or $-70^{\circ} \mathrm{C}$ in $2 \mathrm{SP}$ buffer maintained an infectivity of $83 \%$ and $86 \%$ after storage, respectively. ${ }^{20}$ However, all samples were collected, transported, and processed under identical conditions and thus the observed difference in CT viability between samples most likely represents true biological variation rather than only variation due to study procedures. Finally, assessment of viability by V-PCR is solely based on bacterial membrane integrity, leading to a possible overestimation of bacterial viability, as the presence of dead bacteria with intact membranes cannot be ruled out.

In conclusion, we demonstrated that in a substantial amount of rectal samples (52\%), viable CT could be detected, irrespective of reported anal sex or rectal symptoms. These results suggest that rectal CT in some women might represent a currently ongoing infection rather than just the presence of remnant DNA from dead bacteria or only contamination from an active vaginal CT infection, providing new insight in the debate on the clinical relevance of rectal CT detection in women.

\section{Key messages}

- Viable Chlamydia trachomatis (CT) load was strongly correlated to total CT load in rectal samples.

- Viable CT were detected by viability-PCR from rectal swabs in $52 \%$ of women with quantifiable samples, while in the other half of samples (48\%), no evidence of viable CT was found.

\section{Handling editor Nigel Field}

Contributors PW and CJPAH conceived and designed the study. KJHJ and ML were responsible for data collection. KJHJ and NHTMD-M performed the statistical analysis. KJHJ drafted the manuscript. All authors reviewed and approved the final version of the paper.

Funding The authors have not declared a specific grant for this research from any funding agency in the public, commercial or not-for-profit sectors.

Competing interests None declared.

Patient consent for publication Not required.

Ethics approval Maastricht University Medical Centre Medical Ethics Committee (METC azM/UM no. 10-4-66; 15-6-2011).

Provenance and peer review Not commissioned; externally peer reviewed.

Data availability statement All data relevant to the study are included in the article or uploaded as online supplementary information.
ORCID iD

Kevin J H Janssen http://orcid.org/0000-0001-5521-0521

\section{REFERENCES}

1 Newman L, Rowley J, Vander Hoorn S, et al. Global estimates of the prevalence and incidence of four curable sexually transmitted infections in 2012 based on systematic review and global reporting. PLoS One 2015;10:e0143304.

2 Price MJ, Ades AE, De Angelis D, et al. Risk of pelvic inflammatory disease following Chlamydia trachomatis infection: analysis of prospective studies with a multistate model. Am J Epidemiol 2013;178:484-92.

3 Papp JR, Schachter J, Gaydos CA, et al. Centers for Disease Control and Prevention (CDC). Recommendations for the laboratory-based detection of Chlamydia trachomatis and Neisseria gonorrhoeae-2014. MMWR Recomm Rep 2014;63:1-19.

4 Lanjouw E, Ouburg S, de Vries HJ, et al. 2015 European guideline on the management of Chlamydia trachomatis infections. Int J STD AIDS 2016;27:333-48.

5 Nwokolo NC, Dragovic B, Patel S, et al. 2015 UK national guideline for the management of infection with Chlamydia trachomatis. Int J STD AIDS 2016:27:251-67.

6 van Liere GAFS, Dukers-Muijrers NHTM, Levels L, et al. High proportion of anorectal Chlamydia trachomatis and Neisseria gonorrhoeae after routine universal urogenital and anorectal screening in women visiting the sexually transmitted infection clinic. Clin Infect Dis 2017;64:1705-10.

7 Chandra NL, Broad C, Folkard K, et al. Detection of Chlamydia trachomatis in rectal specimens in women and its association with anal intercourse: a systematic review and meta-analysis. Sex Transm Infect 2018;94:320-6.

8 Kong FYS, Tabrizi SN, Fairley CK, et al. The efficacy of azithromycin and doxycycline for the treatment of rectal Chlamydia infection: a systematic review and meta-analysis. J Antimicrob Chemother 2015;70:1290-7.

9 Ding A, Challenor R. Rectal Chlamydia in heterosexual women: more questions than answers. Int J STD AIDS 2014;25:587-92.

10 Heijne JCM, van Liere GAFS, Hoebe CJPA, et al. What explains anorectal Chlamydia infection in women? Implications of a mathematical model for test and treatment strategies. Sex Transm Infect 2017:93:270-5.

11 Janssen KJH, Dirks JAMC, Dukers-Muijrers NHTM, et al. Review of Chlamydia trachomatis viability methods: assessing the clinical diagnostic impact of NAAT positive results. Expert Rev Mol Diagn 2018;18:739-47.

12 Janssen KJH, Hoebe CJPA, Dukers-Muijrers NHTM, et al. Viability-PCR shows that NAAT detects a high proportion of DNA from non-viable Chlamydia trachomatis. PLoS One 2016;11:e0165920.

13 Nocker A, Cheung C-Y, Camper AK. Comparison of propidium monoazide with ethidium monoazide for differentiation of live vs. dead bacteria by selective removal of DNA from dead cells. J Microbiol Methods 2006;67:310-20.

14 Nogva HK, Drømtorp SM, Nissen H, et al. Ethidium monoazide for DNA-based differentiation of viable and dead bacteria by $5^{\prime}$-nuclease PCR. Biotechniques 2003;34:804-13

15 Jalal $H$, Stephen $H$, Curran MD, et al. Development and validation of a rotor-gene real-time PCR assay for detection, identification, and quantification of Chlamydia trachomatis in a single reaction. J Clin Microbiol 2006;44:206-13.

16 Scidmore MA. Cultivation and laboratory maintenance of Chlamydia trachomatis. Curr Protoc Microbiol 2005; Chapter 11:Unit 11A.1.

17 Rank RG, Yeruva L. Hidden in plain sight: chlamydial gastrointestinal infection and its relevance to persistence in human genital infection. Infect Immun 2014;82:1362-71.

18 Dukers-Muijrers NHTM, Wolffs PFG, Eppings L, et al. Design of the FemCure study: prospective multicentre study on the transmission of genital and extra-genital Chlamydia trachomatis infections in women receiving routine care. BMC Infect Dis 2016;16:381.

19 Benson LS, Martins SL, Whitaker AK. Correlates of heterosexual anal intercourse among women in the 2006-2010 national survey of family growth. J Sex Med 2015;12:1746-52.

20 Aarnaes SL, Peterson EM, De La Maza LM. The effect of media and temperature on the storage of Chlamydia trachomatis. Am J Clin Pathol 1984;81:237-9. 